\title{
急性化膿性胆管炎症例の検討
}

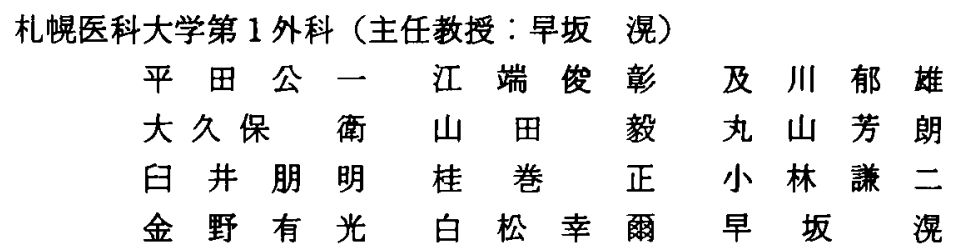

\section{A STUDY OF THE CASES OF ACUTE SUPPURATIVE CHOLANGITIS}

Koichi HIRATA, Toshiaki EBATA, Ikuo OIKAWA, Mamoru OKUBO,

Takeshi YAMADA, Yoshiro MARUYAMA, Tomoaki USUI,

Tadashi KATSURAMAKI, Kenji KOBAYASHI Arimitsu KONNO,

Koji SHIRAMATSU and Hiroshi HAYASAKA

lst Department of Surgery, Sapporo Medical College

(Director : Prof. Hiroshi Hayasaka)

急性閉塞性化膿性胆管资を含む重症化膿性胆管炎の病態は，胆道の閉塞と感染といら 二因子に規定されることが多く, 胆管内が empyema の状態となったもので, 内圧の元進 とともに起炎菌が cholangio-venous refluxにより血中に移行し敗血症性ショックを起 こし，緊急なドレナーシをしない限り救命できない状態を呈するいー4.

過去 9 年間に当教室で経験した22例の重症化膿性胆管炎症例について予後良好例・不 良例の 2 群に分け，臨床所見・䅅過の比較検討を行ない，本症の予後に影旂を与える因 子について検討した。，その結果，予後不良例においては，血小板の减少，多発性肝膿瘍・ リムルステスト陽性・原疾患として悪性腫場の存在・PTCD の施行遅延などを認める症 例が多く，Reynolds の 5 改や一般臨床唡查值（血清総ビリンビン值・トランスアミネー ス値・BUN 値)については特に両群間に差はなかった。 また，一般に悪性腫場における 本症発生率は低いといわれているが，急速閉塞機転を伴らすのる，決して少なくないと 考えられた。

事引用語：急性化膿性胆管炎, PTCD

\section{緒 固}

胆道感染には種々の段階のものがあり, 外科的処置 が急がれるすのとして重症胆管炎がある344. 本症の大 部分は胆道内容に感染が著明であり胆汁うっ滞あるい は胆道閉塞を除去しない限り，改善するものではない。 本症に対して確立した定義はないが, 閉塞の程度と感 染胆汁の性状から, 閉塞性・非閉塞性, 化膿性 - 非化 膿性に分類されることが多い4．なかでも急性閉塞性 化膿性胆管炎は電撃的経過をたどり，早朝の胆道ドレ ナージ以外はまったく救命しえない最重症病態として 理解されている1-4).しかしこの病態は, 前述のよらな
胆管形態および胆汁性状に加えて，Charcot ${ }^{1 / の ~} 3$ 徵あ るいは Reynolds ${ }^{21} 5$ 徵をはじめ数種以上の重篤な 徵候を必須因子として具備しているものと規定されて いるが，報告者によって必ずしも一致していない点で 問題が残されている. 今回は胆道閉塞を伴ない, いわ ゆる化膿性胆汁を示した症例で，Charcotの 3 徵に ショック症状か中枢神経症状を示した症例を重症化䝢 性胆管炎症例とし，なかでも Reynoldsの 5 徽を伴な 万症例を急性閉塞性化膿性胆管炎症例として規定し た.このような化膿性胆管炎の教室経検22症例につい て検討したので報告する。 


\section{検討対象症例}

当教室において1974年 7 月から1983年 6 月までの 9 年間に手術された胆道系疾患は表 1 に示したよらに 933例で,このらち重症化膿性胆管资の発生を認めたの は22症例で，急性閉塞性化膿性胆管炎例が12例含まれ ている. 22症例の原疾患の内訳は，良性疾患が 9 例で このうち遣残結石のために発生したのが 3例あり，ま た覀性疾患は13例で胆管癌10例をはじめ苹頭部癌・乳 頭部癌・胆震癌・原発不明癌が含まれている，急性閉 塞性化显性胆管炎症例は良性疾患症例で 5 例，悪性疾 患症例で 7 例であった，原疾患に対する重症胆管炎あ るいは急性閉塞性化膿性胆管炎の発生頻度の点では, 䏣管癌・胆管結石・乳頭部癌などで高く，とくに前 2 者で絶対数において多かった，重症化膿性胆管炎の予 後良好例は13例でこの5ち良性疾患が7例含まれてい るのに対し，予後不良例は 9 例で悪性疾患が 8 例含ま れている，急性閉塞性化膿性胆管炎の予後良好例・不 良例はそれぞれ 6 例で，前者で良性垁患を 4 例，後者 て悪性疾患を 5 例含んでいる，予後不良例に悪性疾患 が多かった。

\section{1. 予後からみた症例の検討}

次に原疾患における予後とは別に，重症化膿性胆管 炎の予後から教室例を検討してみたい，なお予後良好 例とは, 初回ドレナージ得後 Charcotの3 徵あるいは Reynolds の 5 徽が改善し，原疾患に対する手術目的の ため開腹術がなされたすのであり不良例とはドレナー 䐆後臨床症状の改善を全く認めず，胆管资に起因す
表 1 数室における胆道疾患数

\begin{tabular}{|c|c|c|c|c|}
\hline 疾总名 & \multirow{2}{*}{$\frac{\text { 症例 }}{565}$} & \multirow{2}{*}{$\frac{\text { 工在胆䇺炎例 }}{0}$} & \multicolumn{2}{|c|}{ 予掼 } \\
\hline 他 結 & & & & \\
\hline 胆垔-腿管結石 & 91 & $2(1)$ & $2(1)$ & 0 \\
\hline 地管桔 石 & 61 & $5(4)$ & $4(3)$ & $1(1)$ \\
\hline 肝 内 耤 石 & 22 & 0 & & \\
\hline 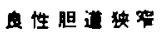 & 8 & 0 & & \\
\hline 先天性胆道疾悤 & 22 & $\mathbf{0}$ & & \\
\hline 腈童 胞 & 34 & 0 & & \\
\hline 昍 & 15 & $1(0)$ & 0 & $1(0)$ \\
\hline 胆管富 & 33 & $10(5)$ & $4(1)$ & $6(4)$ \\
\hline 膵 & 67 & $2(0)$ & 2 & 0 \\
\hline 乳 頭 部 & 9 & $1(1)$ & $1(1)$ & 0 \\
\hline 原 不 明 & 6 & $1(1)$ & 0 & $1(1)$ \\
\hline st & 933 & $22(12)$ & $13(6)$ & $9(6)$ \\
\hline
\end{tabular}

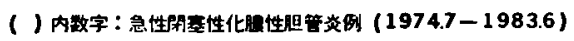

る合併症発生を伴らことで，あるいは臨床症状の充分 な改善を認めぬま早期開腹術を余儀なくされ，その 後細胆管资の発生や合併症発生のために死亡した症例 をいら。

\section{1）本症予啳良好例}

予後良好例13例の内訳を表 2 に示した。このらち急 性閉塞性化膿性胆管炎例は 6 例である。表 $2 \mathrm{a}$ はドレ ナージ術前の臨床所見, $2 \mathrm{~b}$ は検査所見, $2 \mathrm{c}$ は治療法拧 上び臨床経過を要約したものである.男女比 6：7で, 年龄分布は38一74歳で平均60歳である，胆道疾患の既 応は結石症例 7 例中 6 例に認めている。 ショック症状 を 8 例 $(62 \%)$ に，中枢神経症状を10例 $(77 \%)$ に認 めた。原疾患としては，良性疾患 7 例・悪性垁患 6 例

表 2 a 予啳良好例

\begin{tabular}{|c|c|c|c|c|c|c|c|c|}
\hline 症 & 㤡 & & & 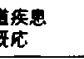 & 現 & $\begin{array}{l}\text { ショック状管 } \\
\text { 血王 } \mathbf{m m H} \mathbf{g}\end{array}$ & 中枢神柽应玦 & 原庆表 \\
\hline 1. N.N. & 8 & 38 & 有 & $\begin{array}{l}\text { 盟雷淡 } \\
\text { 㫜石症 }\end{array}$ & 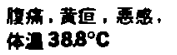 & $89^{( \pm)} 46$ & 的䁌㑔向 & 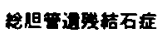 \\
\hline 2. H.F. & 9 & 58 & 有 & 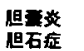 & 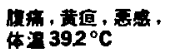 & $78^{(+)} 40$ & 指内力低下 & 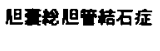 \\
\hline 3. H.E. & 8 & 58 & 有 & 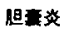 & 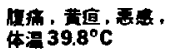 & $76^{(+)} 34$ & 甠眼保向 & 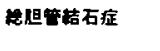 \\
\hline 4. M.H. & $q$ & 46 & 有 & 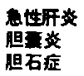 & 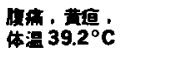 & $68^{(+)} / 32$ & EALR保向 & 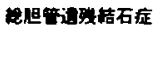 \\
\hline 5. K.K. & 8 & 74 & 有 & 㫜石症 & 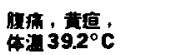 & $82^{( \pm)} 0$ & 不继状態 & 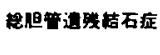 \\
\hline 6. M.N. & $\&$ & 71 & 典 & & 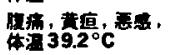 & $70^{(+)} 0$ & $(-)$ & 臨重部酉 \\
\hline 7. M.T. & $\delta$ & 45 & 重 & & 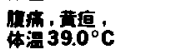 & $86^{( \pm)} / 70$ & $(-)$ & 䎴融部乘 \\
\hline 8. T.K. & q & 79 & 第 & & 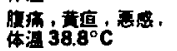 & $102^{\prime}$ & A眼佰问 & 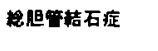 \\
\hline 9. M.N. & $q$ & 65 & 重 & & 晹满 & $82^{( \pm)} 0$ & 不状点 & 上部胆管渵 \\
\hline 10. K.F. & 3 & 59 & 無 & & 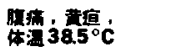 & $78^{(+)} / 60$ & $(-)$ & 下部胆管要 \\
\hline 11. G.S. & s & 69 & 無 & & 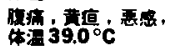 & ${ }_{80}^{(+)} 52$ & 腿傮问 & 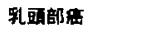 \\
\hline & $\delta$ & 67 & 篇 & & 昆席 & $80^{(+)} 50$ & 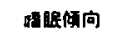 & 下部胆管舟 \\
\hline 13. Y.T. & q & 51 & 有 & 量石症 & 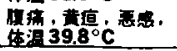 & $72^{(+)} 45$ & 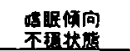 & 怛管蛣石症 \\
\hline
\end{tabular}


表 2 b 予後良好例の検查所見

\begin{tabular}{|c|c|c|c|c|c|c|c|c|c|}
\hline 症例 & 白血球教 & 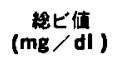 & $\underset{\text { (U) }}{A)_{\text {it }}}$ & $\begin{array}{c}\text { S-GOT } \\
\text { (U) }\end{array}$ & BUN & $\begin{array}{l}\text { 血小懒数 } \\
\times 10\end{array}$ & 愠汁培签 & $\underset{\text { test }}{\text { Limulus }}$ & 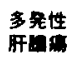 \\
\hline 1 & 24400 & 5.2 & 148 & 25 & 16 & 17.7 & $\begin{array}{l}\text { Enterobacter } \\
\text { Klebsiolla }\end{array}$ & $(-)$ & $(-)$ \\
\hline 2 & 19800 & 10.2 & 356 & 95 & 14 & 27.1 & E. coll & $(+)$ & $(-)$ \\
\hline 3 & 18300 & 10.2 & 209 & 187 & 14 & 23.9 & E.coli & $(-)$ & $(-)$ \\
\hline 4 & 18000 & 10.4 & 304 & 93 & 16 & 19.4 & E.coli & $(+)$ & $(-)$ \\
\hline 5 & 12200 & 8.4 & 467 & 45 & 25 & 17.1 & $\begin{array}{l}\text { B. fragillis } \\
\text { Enter obacter }\end{array}$ & $i-1$ & $(-)$ \\
\hline 6 & 24100 & 19.2 & 346 & 140 & 41 & 16.6 & $\begin{array}{l}\text { Staphyloceccus } \\
\text { aureus and } \\
\text { epider midis }\end{array}$ & $(-)$ & $(-)$ \\
\hline 7 & 28500 & 22.2 & 608 & 38 & 20 & 11.9 & Klebsiella & $(+)$ & $(+)$ \\
\hline 8 & 12600 & 5.9 & 1404 & 200 & 27 & 25.6 & E.coli & $(+)$ & $(-)$ \\
\hline 9 & 15000 & 18.6 & 990 & 190 & 19 & 11.3 & Klebsiella & $(+)$ & $(-)$ \\
\hline 10 & 11400 & 34.1 & 1401 & 120 & 8 & 33.1 & $\begin{array}{l}\text { Staphylococcus } \\
\text { opldermidis }\end{array}$ & $(+)$ & $(+)$ \\
\hline 11 & 14000 & 23.6 & 441 & 64 & 23 & 8.5 & $\begin{array}{l}\text { Staphylococcus } \\
\text { epldermidis }\end{array}$ & $(-)$ & $(+)$ \\
\hline 12 & 11000 & 10.5 & 140 & 98 & 18 & 11.6 & 换出せず & 晹行せず & $(+)$ \\
\hline 13 & 14500 & 8.5 & 305 & 38 & 10 & 8.3 & E.coli & $(+)$ & (-) \\
\hline
\end{tabular}

表 2 c 予後良好例の術式と臨床経過

\begin{tabular}{|c|c|c|c|c|}
\hline 症 例 & $\begin{array}{l}\text { トレナージまでの期间 } \\
\text { (38 }\end{array}$ & 手術方法 & 迥 & 原疾䓯予譺 \\
\hline 1 & 5 日 & PTCD & $\begin{array}{l}\text { 淟床症状改意 } \\
58 \text { 病日退院 }\end{array}$ & 生 (8年2 2 月) \\
\hline 2 & 4 日 & 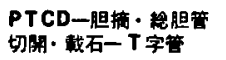 & 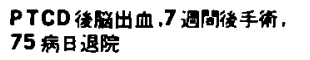 & 生 (6年5力月) \\
\hline 3 & 5 日 & 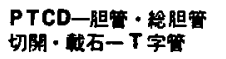 & $\begin{array}{l}\text { ショツク改書，44 日後手術，75 } \\
\text { 病日遮院 }\end{array}$ & 生 (5年2力月) \\
\hline 4 & 6 日 & 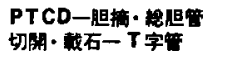 & $\begin{array}{l}\text { ショツク改書，18 日後手術，38 } \\
\text { 病日退院 }\end{array}$ & 生 (4年6力月) \\
\hline 5 & $4.5 \mathrm{E}$ & 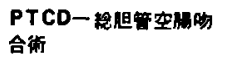 & 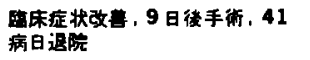 & 生 ( 2 年 9 力月) \\
\hline 6 & 6 日 & PTCD-内蕰術 & 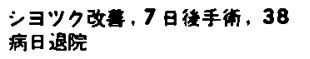 & 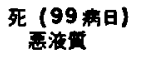 \\
\hline 7 & 4 日 & PTCD一内盘術 & $\begin{array}{l}\text { 踇床症状改書，27日摞手術,57 } \\
\text { 病日枟医 }\end{array}$ & 死 (134 病日) \\
\hline 8 & 7 日 & 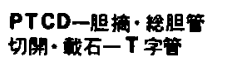 & 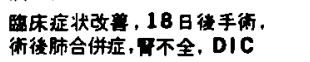 & $\begin{array}{l}\text { 死 }(30 \text { 病日) } \\
\text { 肺炎 }\end{array}$ \\
\hline 9 & 3 日 & PTCD & ショック改書，手術不能で靰医 & 死 (52病日) \\
\hline 10 & 4 日 & $\begin{array}{l}\text { PTCD-睡頭十二指腸 } \\
\text { 切艅 }\end{array}$ & シヨツク改害，32日後手術 & 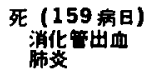 \\
\hline 11 & 6 日 & $\begin{array}{l}\text { PTCD一塐頭十二指得 } \\
\text { 切除 }\end{array}$ & 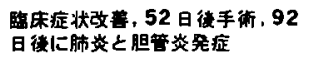 & 死 (114稆日) \\
\hline 12 & 2 日 & PTCD-T字管 & ショック改萻，35 日得手術， & 死 (80病日) \\
\hline 13 & 2 日 & PTCD-T 字管 & 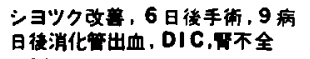 & 死 (14 病日) \\
\hline
\end{tabular}

で急性閉塞性化膿性胆管炎例は前者 4 例・後者 2 例で ある（表 2 a）.白血球数はいずれる10,000以上で 11,000-28,500に分布し，統ビリルビン值はいずれる $5 \mathrm{mg} / \mathrm{dl}$ 以上で, アルカリホスファーターゼ値・GOT 値は一般に軽一中程度上昇を示したか;，血清尿素窒素 值については 1 例（症例 6）のみが明らかな異常値を 示しただけであった。血小板数 $10^{5} / \mathrm{mm}^{3}$ 以下の症例は, 症例11・13の 2 例だけであった。胆汁培養に打いて同 定された細菌の種類はE.coli が最る多く，次いて
Enterobacter, Staphylococcus, Klebsiella なとが多 かった：末梢静脈血を用いてのリムルステスト陽性例 は7 例（恰定症例中 $58 \%$ )で，またPTC 造影所見での 多発性肝膿瘍合併例は 4 例であった（表 2 b). 初回胆 计瘦造設術としては， $38^{\circ} \mathrm{C}$ 以上発熱後 2-7 日目にい ずれの症例に対してすPTCDがなされており，本症の 改善を待ってから原疾患に対する手術が行なわれた。 PTCD 後の合併症としては症例 2 で脳出血を認めた だけである。なお原疾患の予後としては，良性疾患例 
で術後 9 日目に大量消化管出血の発生に引き続いて DIC・骨不全の発生した症例13と㭪後まむなく肺炎を 生し，骨不全，DIC が発生した症例 8 の 2 例を除く 5 例恃存命中である。悪性疾患の 6 例は，いずれも1一数 カ月後に死亡している(表 $2 \mathrm{c}$ ).

\section{2) 本症予後不良例}

予後不良例 9 例の内訳を表 3 に列記した。この5ち Reynolds 5 改を備えたすのは 6 例である. 男女比5： $4 て ゙$, 年齢分布は47一73歳で平均60歳であった。 ショッ $\eta$ 症状を 7 例 (78\%) に，中枢神程症状を 8 例（89\%） に認めた。なお原疾患としては胆石症 1 例，悪性腫堭 8 例である(表 $3 \mathrm{a}$ ). 白血球数は9,800-28,600に分布 し，総ビリルビン值は6.5-31.1mg/dl に分布し，とく に $10 \mathrm{mg} / \mathrm{dl}$ 以上を示した症例が 8 例と大部分を占め た.アルカリホスファターゼ值, GOT 值は，予後良好
例と同様軽一中程度上昇を示した。血清尿素窒素値は 正常値上限（20）をやや上回った症例が多く，とくに 症例21では著しい高值を示した。血小板数は10個/ $\mathrm{mm}^{3}$ 以下の症例が 5 例 $(56 \%)$ で，105/ $\mathrm{mm}^{3}$ をわずか に上回る症例が 3 例と少なくなかった。胆汁培養で同 定された細菌に特定の傾向はなかった。りムルステス 卜陽性例は，測定症例 8 例全例が陽性であった。 また 多発性肝膿場合併例は 5 例であった（表 $3 \mathrm{~b}$ ). 予後不 良群 9 例中 1 例（症例68例）では，ドレナージ術はな されていないが他の 8 例に対しては初回胆汁瘦過設法 としてPTCDを施行している。ショック症状を伴なっ た 7 例中 5 例に一時的な改善傾向を認めたか PTCD 後早期に胆道系に拁ける合併発生などのため，全身状 態がますなく不良となり死亡した症例が多い，とくに 症例 $14 ， 15 ， 20 ， 22$ などは短時日内に DIC や多蔵器不

奉 3 a 予啳不良例

\begin{tabular}{|c|c|c|c|c|c|c|c|c|}
\hline 症 & 列 & & & 疾意 & 現 & $\begin{array}{l}\text { ショック状虑 } \\
\text { 血王mmHg }\end{array}$ & 中枢神程症状 & 原疾量 \\
\hline 14. H.M. & 9 & 52 & 市 & 胆石症 & 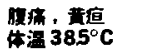 & $70 / 50$ & 不程状点 & 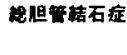 \\
\hline 15. T.S. & 9 & 57 & 年 & & 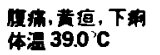 & $90 / 40$ & 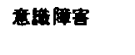 & 下部㫜管葆 \\
\hline 16. Y.S. & 8 & 69 & 怎 & & 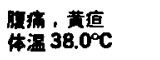 & $74 / 48$ & $(-)$ & 怛五禹 \\
\hline 17. M.T. & 8 & 47 & 魚 & & 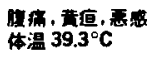 & ${ }_{80 / 42}^{(+)}$ & 吟造倾向 & 中部胆管荡 \\
\hline 18. A.M. & ? & 67 & 策 & & 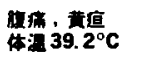 & $\begin{array}{c}(+) \\
40 /-\end{array}$ & 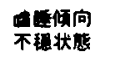 & 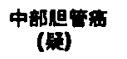 \\
\hline 19. G.N. & 8 & 58 & 無 & & 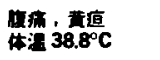 & ${ }_{84}^{( \pm)} / 58$ & 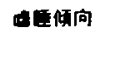 & 中部胆管盘 \\
\hline 20. C.I. & 8 & 59 & 䋣 & & 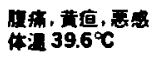 & $\frac{(+)}{70 / 30}$ & 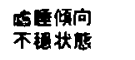 & 下部㫜管囟 \\
\hline 21. T.T. & t & 60 & 㫮 & & 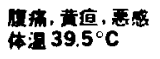 & $78 / 40$ & 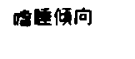 & 肝陪兽 \\
\hline 22. K.N. & q & 73 & 素 & & 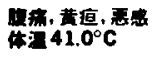 & $60^{(+)}$ & 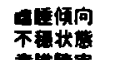 & 中部胆管菑 \\
\hline
\end{tabular}

表 3 b 予後不良例の梌变所見

\begin{tabular}{|c|c|c|c|c|c|c|c|c|c|}
\hline 症 则 & 白血球数 & 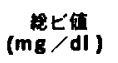 & $\begin{array}{l}A \mid-P \text { 值 } \\
\text { (U) }\end{array}$ & $\begin{array}{c}S-G O T \\
\text { (U) }\end{array}$ & BUN & $\begin{array}{c}\text { 血小板视 } \\
\times 10^{4}\end{array}$ & 成汁唔营 & Limulus & 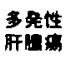 \\
\hline 14 & 12600 & 18.1 & 246 & 47 & 29 & 11.8 & E.coli & $(+)$ & $(-)$ \\
\hline 15 & 9800 & 30.5 & 776 & 93 & 25 & 10.7 & $\begin{array}{l}\text { Salmonella } \\
\text { typhi }\end{array}$ & $(+)$ & $(+)$ \\
\hline 16 & 17600 & 31.1 & 1149 & 110 & 11 & 7.8 & $\begin{array}{l}\text { Staphylococcus } \\
\text { epldermidis } \\
\text { Acinetobacter } \\
\text { calcosceticus }\end{array}$ & $(+)$ & $(+)$ \\
\hline 17 & 13600 & 6.5 & 588 & 120 & 48 & 18.6 & $\begin{array}{l}\text { Serratia } \\
\text { marcescens } \\
\text { Citrobacter } \\
\text { freundl }\end{array}$ & $(+)$ & $(-)$ \\
\hline 18 & 9800 & 25.4 & 415 & 123 & 35 & 5.2 & E.coli & $(+)$ & $(-)$ \\
\hline 19 & 11700 & 14.8 & 500 & 280 & 8 & 9.5 & 施行せず & 勆行せず & $(-1)$ \\
\hline 20 & 28600 & 11.2 & 757 & 69 & 25 & 8.2 & Hafnia & $(+)$ & $(+)$ \\
\hline 21 & 19800 & 17.3 & 262 & 55 & 143 & 9.7 & $\begin{array}{l}\text { Pseudomonas } \\
\text { aeruginosa }\end{array}$ & $(+)$ & $(+)$ \\
\hline 22 & 20000 & 120 & 728 & 201 & 21 & 11.7 & $\begin{array}{l}\text { Klebsiella } \\
\text { preumonia }\end{array}$ & $(+)$ & $(+)$ \\
\hline
\end{tabular}


表 3 c 予後不良例の街式と臨床経過

\begin{tabular}{|c|c|c|c|c|}
\hline 症例 & 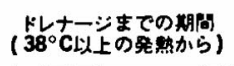 & 手政方法 & 释 & 原疾惫予啳 \\
\hline 14 & 34 時間 & PTCD & 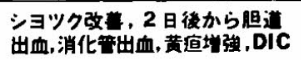 & 死 (40病日) \\
\hline 15 & 10 日 & PTCD & 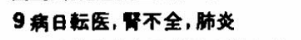 & 死 (30病日) \\
\hline 16 & 5 日 & PTCD & 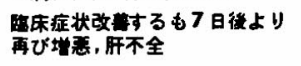 & 死 (52病日) \\
\hline 17 & 7 日 & 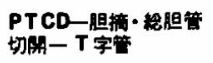 & 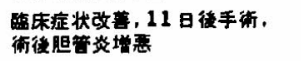 & 死 (203病日) \\
\hline 18 & 無 & 無 & 2房日霓不全，䚽不全 & 死 (11 病日) \\
\hline 19 & 6 日 & PTCD & 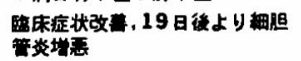 & 死 (35 病日) \\
\hline 20 & 2 日 & PTCD & I 舟日DIC & 死 (3 病日) \\
\hline 21 & 25 日 & PTCD一内璂街 & 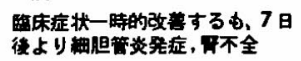 & 死 $(83$ 病日) \\
\hline 22 & 5 日 & PTCD & 3病日に艘不全,腅死 & 死 (10病日) \\
\hline
\end{tabular}

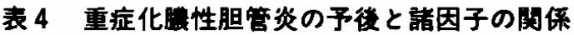

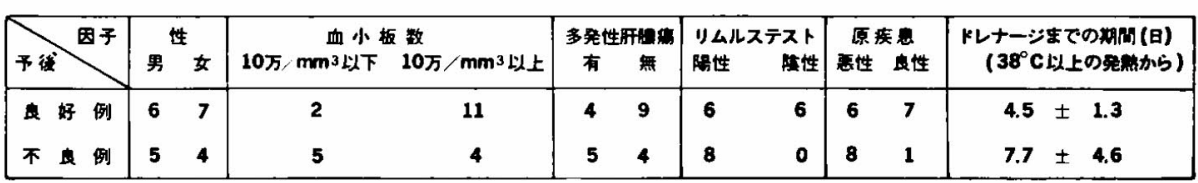

全を発生し，全身状態の改善を全く認めずに死亡して いる(表 $3 \mathbf{c}$ )。な拈症例14，20，22では PTCD 後胆汁 流出が不良で，胆汁産生が既に不良であったか，ドレ ナージ効果不充分例と考兄られている．次に症例の一 部を紹介する。

\section{2. 症例}

症例 6 ：当科への転医29日前に黄疸に気づき，その 19日後に某病院内科へ入院した。入院 4 日後に発熱を 6 日後に收縮期血王の低下を認めたため当科へ転医し てきた。急性閉塞性化膿性胆管炎の診断で PTCD を施 行した，膿性胆汁の流出と胆管末端部付近での完全閉 塞および大きな膿瘍とともに多発性肝膿瘍を認めた （図 1). 臨床症状はすぐに改善し，150-350 $\mathrm{ml}$ の膿性 胆汁を数日間認めたが間もなく正常胆汁の流出となっ た。肝膿愓は急速に縮少したが衰胞様状態は持続し, 完全消失することはなかった，開腹時所見で摘出不能

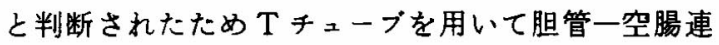
絡形成術を施行したか，術後第99病日目で死亡した。

症例11：歴肺症で治療をうけていたが，黄疸をとも ない貧血・発熱も生じたため当院内科へ転医した，悪 感戦慄を生じ, 重症胆管炎の診断で当科で PTCD を施 行した。間もなく良好な胆汁流出を認めるとともに臨 床症状の改善を認めたが，糖尿病の合併と出血傾向・ 呼吸障害（血中酸素分圧の低下）などが生し，早期の 手術にふみきれなかった. PTCD 施行後53日目に乳頭

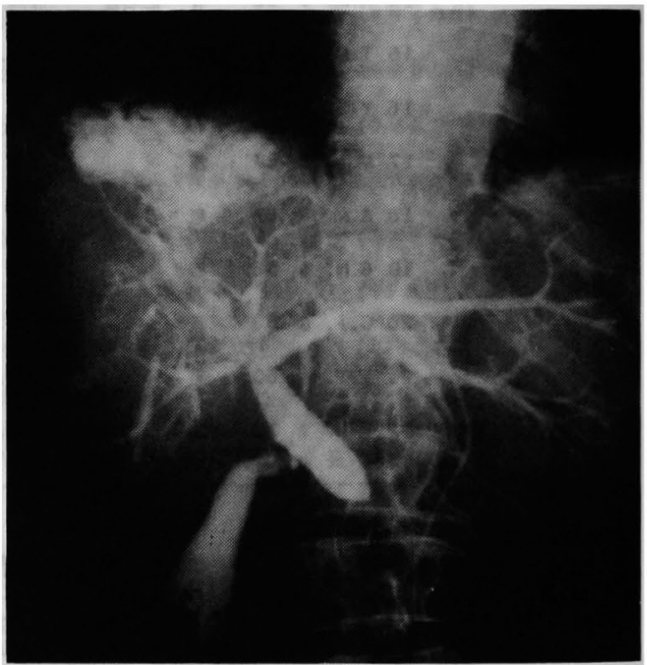

图 1 症例 6 の入院時 PTC 所見. 右葉に大きな朖渴 を含め多発性膿瘍を認める。

部癌の診断で荤頭十二指腸切除術を施行した。得後出 血傾向の再現之間質性肺炎を合併し，呼吸不全となり 開腹術後61日目に死亡した。図 2 は術後10日目の Thromboelastogram を示している.

症例22：虚血性心疾患・黄疸で某病院へ入院したか， 高熱と頿眠傾向および理解不能な言動に及んだため当 科一転医した.PTC 造影所見で中部胆管領域での完全 閉塞を認めた. ドレナージからの胆汁排出量は25-100 


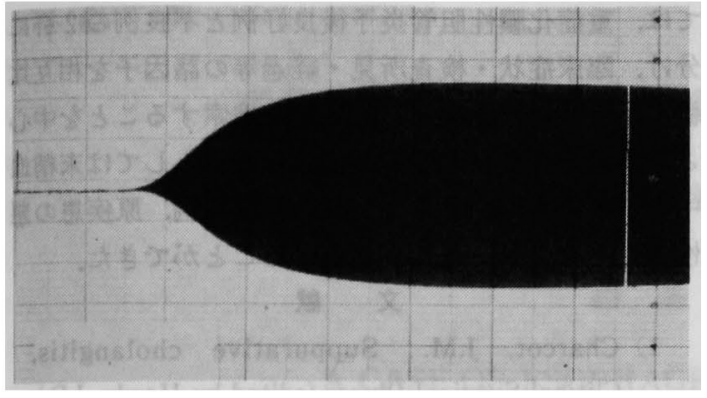

图 2 症例11の衍徣10日目の Thromboelastogram. ほば正常パーンを示すが応時間の遅延（20分） を琶める。

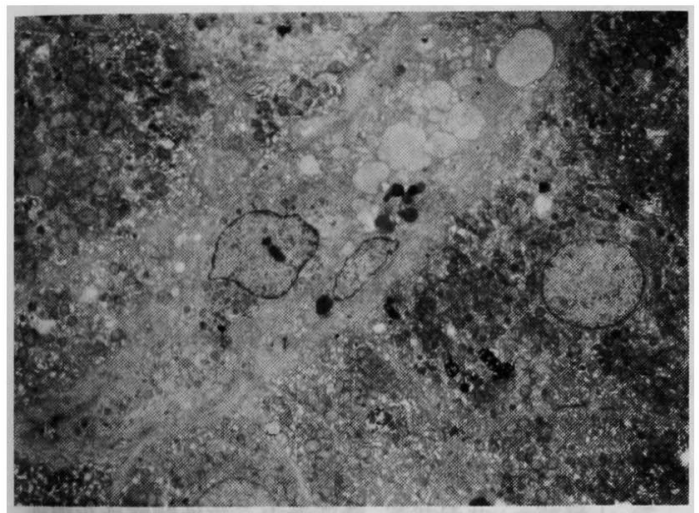

图 3 症例22の肝生検材料奄影所見. 肝細胞内小器官 の变性所見および類洞内細胞凝集反応と膨大化した 血小板を多数認める。

$\mathrm{ml}$ と少なかった。 PTCD 施行 3 日目から意識消失と 大発作が生じ，脳出血が推定されたため人工呼吸器下 で管理した，5日目のメンジー二針で訮生検を行ない, 奄彯的に検索したところ, 肝細胞の不可逆的变性と類 洞内での膨化血小板・間葉系細胞の集族や細胞内小器 官の遊離などを認めた（图 3 ），第10病日に DIC·堅不 全・心不全のため死亡した，剖検の結果，肝転移を伴 なら中部胆管癌で，脳脈絡膜上出血も認められた。

责按

重症胆管炎症例には化膿性変化を伴なわない閉塞性 胆管资症例が多いことも周知の事実であるが(15)，今回 は胆道閉塞機転に化膿性胆管炎発生の成因のある症例 について検討を加えた，胆管炎の中で最重篤型として 知られる急性閉塞性化㬴性胆管资症例を12例経験して いるが，本症に対する定義については報告者により多 少相違がみられる ${ }^{316) 7)}$ ．教室では，(1) 上腹部痛(自発 痛・压痡)，（2）悪感戦慄を伴な5高熱（38 ${ }^{\circ} \mathrm{C}$ 以上),

（3）黄疸(血清総ビリルビン值 $5 \mathrm{mg} / \mathrm{dl}$ 以上)，(4) 萼
眠傾向を含め精神症状，(5) 収縮期血圧80以上，(6) 白 血球数 10,000 以上, (7) 胆管内膿性胆计うっ滞の証明, （8）胆管内胆汁の培善で細菌の証明，の全因子が確認 された症例を急性閉塞性化膿性胆管炎と定義してい る. しかし，他の報告者 ${ }^{78)}$ む指摘しているよ5に臨床 像中臨床検查成績では，例光ば精神症状やショック症 状を伴なわくなくとも，本症に含まれるべき症例の多 いことす事実であり，今後の詳細な検討のらえでより 正確な分類がなされるすのと考えられる。

症例18は，死亡前に胆管ドレナージがなされておらら ず,剖検時に胆管内朖性胆汁が証明されたものである。 Reynoldsの 5 徵を具備しており rectrospectiveには 急性閉塞性化膿性胆管资症例と考えられるが，死亡前 に確診されていないため疑診例としており，その数に 含んでいない，なお胆汁培養を行ななった場合，全例 に細菌が同定されている。しかし，島田ら9)-11が指摘 しているよ5な混合感染例あるいは㒖気性菌同定例が 少ないのは，技術的な問題が残されているとも考えら れ，今後の症例に対して慎重な検討がなされるべきも のと思われる.

重症化膿性胆管炎の重症化因子としては，いうまで むなく胆道閉塞の存在であり，治療法としては早期の 胆管閉塞解除をあげることができる，たとえ胆管资症 状がなくとも肝外閉塞性黄庭に対しては，できるだけ 早期の減黄ドレナージか閉塞原因除去手術がなされる べきであろらか，とくに重症胆管炎が発生した場合に はトレナーシ術施行の機会を逸すると，電撃的経過を とり救命しえぬことも少なくない(47)12)13)。ドレナーシ を行なう時期について高田らかは，(1) 保存的療法で48 時間以内に改善をみないもの, (2) Charcot の 3 徵の増 悪, (3) 意識障害やショックの発生,などが重要なボイ ントと指摘しており，われわれる血中ェンドトキシン 量測定 ${ }^{14)}$ 含めて, 菣急ドレナーシの時期を選択して いる.

教室例に対するドレナージ法としては全例に PTCDを行っているが，本法は侵裂が少なく，とくに リスクの覀い重症胆管炎症例に対しては優れた術式と いえる。しかし肝内胆管に瞵接する門脈に穿刺した場 合，胆管内に出血を生じ凝血塊がしばしばドレナーシ 効果を阻止することがある，われわれの経験例の多く もドレナージ術後 2-3 日間は血液㠜塊の胆道内存在 のため充分な排出量がなく，一層病態を増悪させるこ とああり，より注意深い操作が望まれた。なお予後不 良例の中には全释過において非淮量が非常に少ない症 
例があった。その理由としては，広汎な肝細胞壊死を きたし産生胆汁量が少ない場合，細胆管構築の破壊に 伴な5胆汁流路障害の発生, 産生胆汁成分の变化に伴 なら胆汁粘稠度の増強，あるいは肝内胆管への悪性細 胞漫潤などが考えられる。胆道閉塞の原因が明らかに 結石である場合には，PTCD 操作により門脈系損伤を きたし菌血症を誘発したり，あるいは増悪させる危険 性があること，最近の呼吸・循環管理法の向上で術中 全身管理が安全に行なわれるよ5になったことなどの 理由で，PTCDよりは開腹により確実に胆管ドレナー シを選択し，できれば結石症に対する構治術を同時に 行ならべきといら意見もある ${ }^{15)}$. しかしどのよらな治 療法を選択しょらとも，このよらな重症例に対しては 高田ら川の指摘するよ5に術式に対する熟達度が最も 重要な要因であろ5。彼らはこれを前提条件として， 胆管抬張例に対してPTCDを，また結石例ではT チューブによるドレナージ効果が期待できると判断さ れた症例に開腹術をすするている.

次に教室症例に抢ける重症化膿性胆管炎の予後とそ れを左右しらる諸因子との関係を検討してみたい，表 4 に示したように予後良好例と不良例の間で性差はみ られないが，血小板减少例 (10万/ $/ \mathrm{mm}^{3}$ 以下) が前者で $15.4 \%$ でるのに対し，後者で55.5\%と多く，多発性 肝膿煬発生例が前者で $30.8 \%$ ，後者で55.5\%，リムル ステスト陽性例は前者で50\%，後者で $100 \%$ ，原疾患が 悪性である症例数は前者で $46.2 \%$ ，後者で $88.9 \%$ で あった。また $38^{\circ} \mathrm{C}$ 以上の発熱が発生してからドレナー ジが成されるまでの期間については，平均で前者で 4 ， 5 日，後者で7.7日，一般に不良例ではドレナージまで の時間は長かった。このように予後に影㸷を与える因 子としては，末梢血血小板数，リムルステスト陽性例, 胆道閉塞の原疾患が悪性であること，ドレナージ施行 荤延例などをあげることができる。なお他の臨床症状， 臨床検查成績，胆道閉塞部位などについては両群間で 差を認めなかった。

一般に悪性腫湯における重症化膿性胆管炎とくに急 性閉塞性化朖性胆管炎の発性頻度は少ないと考えられ ているが16), 教室例では必ずしる少ないとは言えず, 覀 性尰瘍による不完全閉塞状態の持続時に胆道感染を合 併し，閉塞状態となって急速に重症胆管炎化すること も少なくないと考えられる。

\section{結 論}

急性閉塞性化膿性胆管炎を含む重症化膿性胆管炎に ついて教室症例22例を中心に検討した。検討方法とし
ては，重症化膿性胆管炎予後良好例と不良例の 2 群に 分け，臨床症状・検査所見・経過等の諸因子を相互比 較し，予後に影響を与える因子を検索することを中心 とした，その結果，予後不良化の因子としては末梢血 中血小板减少例，リムルステスト陽性例，原疾患の惠 性例，ドレナージ遅延例をあげることができた。

\section{文部}

1) Charcot, J.M.: Suppurative cholangitis, Clitical Surgical Illness (edited by Hardy, J.D.), Saunders Co., 1971.

2) Reynolds, B.M. and Dargan, E.L.: Acute obstructive cholangitis. A distinct clinical syndrome. Ann. Surg., $150: 299-303,1959$.

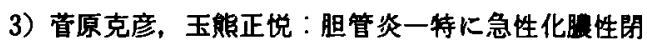
塞性胆管炎について一, 診断之治庰，65： 648-653, 1977.

4）高田忠敬, 羽生富士夫：重症胆管炎の病態と治癔 について，胆と羘， I: 999-1008，1980.

5) Saik, R.P., Greenburg, A.G. and Farris, J.M.: Spectrum of cholangitis. Am. J. Surg., $130: 143$ $-150,1975$.

6）多賀碩幸男，船富 享：急性閉塞性化晨性胆管炎 の概念，胆と苏， $1: 949-954 ， 1980$.

7）土屋凉一，井沢邦英，䅧部孝史：急性閉塞性化儤性 胆管炎の病態，胆之羘， $1: 961-970 ， 1980$.

8）高田忠敬, 内田泰彦, 中村光司：合併症をつ胆石 症の治療関する恰討, 棕合臨床, 26：184-192. 1977.

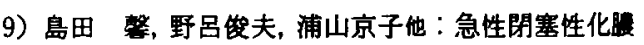
性胆管资の細菌学的検討，胆と羘，1：985-989， 1980.

10）代田明郎, 三樹 勝, 吉岡正智他：急性胆管炎の病 態, 臨床成人病，6：1209-1225，1976。

11) Lykkegaard, M. and Justesen, T.: Anaerobic and aerobic bacteriological studies in biliary tract disease., $11: 437-446,1976$.

12）玉熊正说，磯山徽：急性閉塞性化脿性胆管资の 病態，胆と膦， $1: 955-960 ， 1980$.

13）黑田慧：胆道ドレナーシの意義，胆と䐙， 4 ： 5-9, 1983.

14）早坂 滉, 西村 亘, 川山照雄：稩菌性ショックと エンドトキシン, 外科, $36: 1429-1433 ， 1974$.

15）岡村隆夫：急性閉塞性化胎性胆管炎の治癔, 胆と 羘, $1: 991-998,1980$.

16）土屋幸浩, 大藤正雄, 正原正明：急性閉塞性化䝢性 胆管资の病態，胆と丵， $1: 971-984 ， 1980$. 